\title{
Osteonecrosis of the Iliac Wing and Sacral Insufficiency Fractures After Radiotherapy: Case Presentation
}

\author{
Radyoterapi Sonrası Iliak Kanadın Osteonekrozu ve Sakral Yetersizlik Fraktürleri: \\ Olgu Sunumu
}

(D) Esra Cansu Selbes, (D) Ezgi Yıldız Güvercin, (D) Ece Çınar, (D) Simin Hepgüler, (D) ipek Tamsel* Ege University Faculty of Medicine, Department of Physical Medicine and Rehabilitation, Izmir, Turkey *Ege University Faculty of Medicine, Department of Radiology, Izmir, Turkey

\section{Abstract}

Iliac wing osteonecrosis coexisting with sacral insufficiency fracture rarely causes low back pain. Radiotherapy (RT) applied to the pelvic area is an important precipitating factor. Here, we present a patient who was referred to our outpatient clinic with mechanical lower back pain that was present for 3 months. The patient had received RT to the pelvic region due to colorectal cancer. Contrast-enhanced magnetic resonance imaging studies revealed iliac wing osteonecrosis and sacral insufficiency fracture. After ruling out the possibility of metastasis and making a definitive diagnosis, the patient was followed-up and bed rest and calcium and vitamin D supplementations were recommended. Despite these precautions, the patient still developed another sacral insufficiency fracture. Mechanical low back pain has a myriad of etiologies and standard X-rays may underdiagnose rarer causes of pain, such as osteonecrosis and insufficiency fractures. Clinical suspicion of these entities, especially in patients with a history of RT, may help in diagnosis and treatment.

Keywords: Fracture, low back pain, osteonecrosis, radiotherapy, rectal neoplasms

\section{$\ddot{O z}$}

iliak kanadın osteonekrozu ve eşlik eden sakral yetersizlik fraktürü, bel ağrısının nadir sebeplerindendir. Pelvik bölgeye uygulanan radyoterapi (RT), bu klinik tabloların gelişmesine yol açan faktörlerden birisidir. Bu olgu sunumunda, polikliniğimize 3 aydır süren mekanik bel ağrısı ile başvuran bir olgudan bahsetmekteyiz. Hasta kolorektal kanser tanısı ile pelvik bölgeye RT almıştı. Kontrastı manyetik rezonans görüntüleme incelemesinde iliak kanatta osteonekroz ve sakrumda yetersizlik fraktürü saptandı. Metastaz dışlandıktan ve tanı kesinleştikten sonra hastaya yatak istirahati, kalsiyum ve D vitamini desteği ile izlenen olguda ikinci bir sakral yetersizlik fraktürü gelişti. Mekanik bel ağrısının çok çeşitli sebepleri olup direkt grafiler, osteonekroz ve yetersizlik fraktürü gibi daha nadir görülen tanıları saptamada her zaman yeterli olmayabilir. Özellikle RT öyküsü bulunan hastalarda, klinik şüphe tanı ve tedavi açısından yardımcı olacaktır.

Anahtar kelimeler: Fraktür, bel ağrısı, osteonekroz, radyoterapi, rektal neoplazmlar

\section{Introduction}

Osteonecrosis is defined as ischemic damage to bone and bone marrow cellular components. Osteonecroses can be classified mainly as primary or secondary (1). Primary osteonecrosis occurs without a known precipitating factor. Whereas secondary osteonecrosis develops as a result of bone ischemia that is caused by direct damage to the vasculature, by radiation injury, dysbarism or in certain disease conditions such as alcoholism, steroid use, immune suppression, sickle cell anemia, rheumatoid arthritis and systemic lupus erythematosus that hinder circulation of the bone tissue. Osteonecrosis may also develop due to direct damage to the bone and bone marrow, in the course of fractures or dislocations (2).

Here we present a case with iliac wing osteonecrosis and sacral insufficiency fracture that developed following radiotherapy (RT) to the pelvic region.

\section{Case Report}

A 70-year-old female patient was admitted to our outpatient clinic with low back pain with a mechanical character that had started 3 months ago and had worsened in the last 1 month. Pain was constant, increased with movement and decreased 
with rest, and did not spread to other regions. However, she also stated that her pain was worse at night and awoke the patient from sleep. Patient did not report urinary or fecal incontinence. When questioned about her medical history, it was inferred that she had received treatment for colorectal cancer 2 years previously. After surgery, she had received 30 sessions of RT to the sacral region, with a total dose of a 59.4 Gy. During physical examination, lumbar movements were painful in all directions. Sacrum and L5 vertebra were painful on palpation, bilateral upper and lower extremity joint ranges of motion and muscle strength were normal. Lumbar range of motion measurements for flexion, extension and bilateral lateral flexion were $50^{\circ}, 10^{\circ}$ and $15^{\circ}$ respectively. Deep tendon reflexes were normoactive. No pathological reflexes or sensory deficits were detected. A lumbar magnetic resonance imaging (MRI) examination was ordered to detect any possible metastatic lesions or pathological fractures considering the patient's history of cancer. Post contrast T1weighted images showed a hypointense line of insufficiency fracture in the sacrum and revealed an osteoradionecrosis area in the subcortical region adjacent to the sacroiliac joint in the left iliac wing (Figure 1).

The patient was consulted with orthopedics for the insufficiency fracture, surgery was not recommended. She was put on bed rest and was started on oral analgesic therapy, calcium supplementation and vitamin D. Since the patient was primarily followed up by radiation oncology, a consultation was made. Colonoscopy and tumor marker control after three months was recommended. Osteoporosis tests came back normal.

In the third month MRI control, intense bilateral bone marrow edema was seen in both sacral wings and was reported as bilateral sacral insufficiency fracture (Figure 2). Patient's symptoms persisted. She was prescribed another course of analgesics. We obtained consent from the patient for the case report.

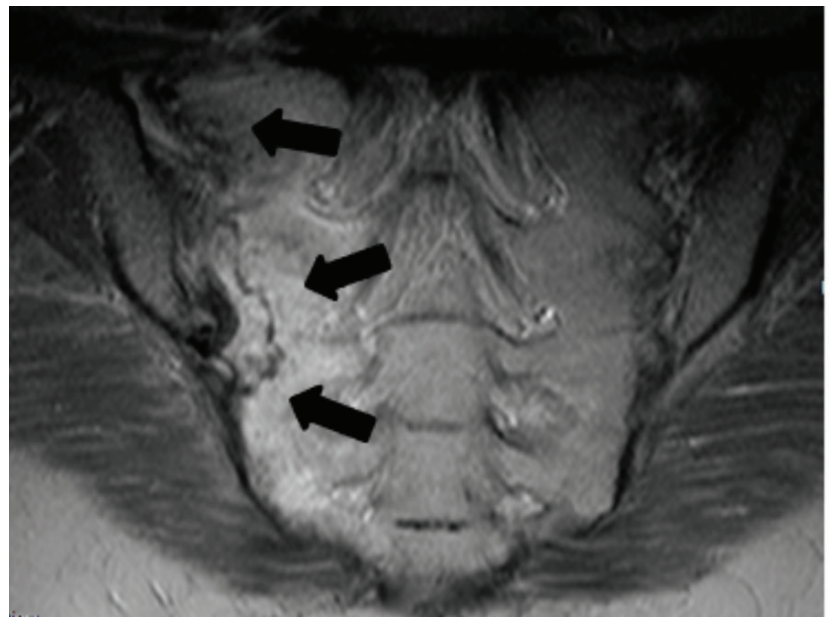

\section{Discussion}

RT is part of standard care for the treatment of pelvic malignancies. Radiation can cause changes in the skeletal system depending on the age and gender of the patient, and size of the radiation field (3). Most important of these changes are radiation osteitis, osteoradionecrosis and insufficiency fracture (4). These changes are together grouped as radiation-induced reactions (RIR) (1). The pathophysiology of RIR is not completely understood, it is believed to result from a toxic response that leads to increased endothelial permeability of the bone marrow sinus in addition to cytoplasmic swelling, and rapid decline in bone marrow cells (3). The sacral bone is commonly affected by RIR due to the amount of red bone marrow in the central pelvic radiation area, so $\mathrm{RT}$ induced osteonecrosis is most commonly seen in the sacrum (3). Osteonecrosis of the iliac wing is rare. Radiation osteitis tends to occur early (average 4 months) and

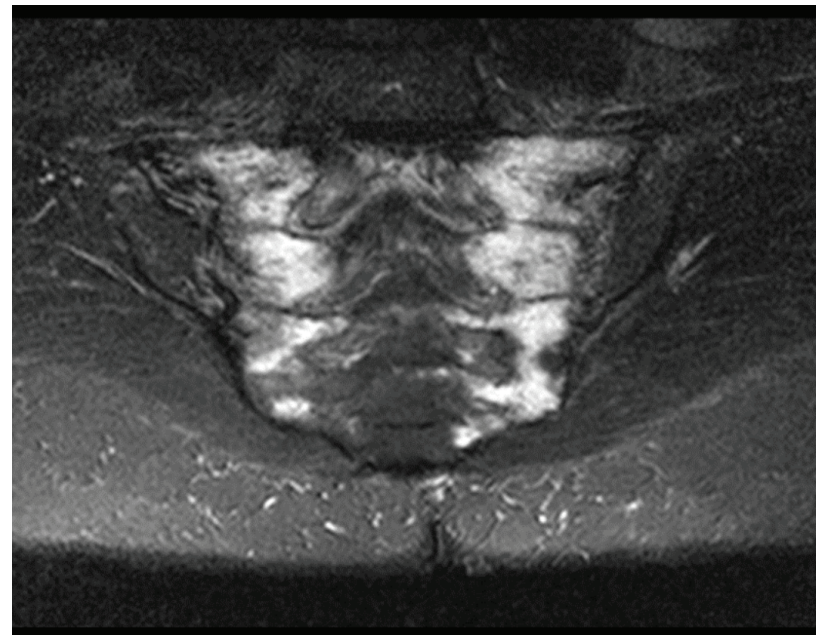

Figure 2. STIR sequence shows diffuse fatty marrow changes of sacrum that is compatible with post radiation changes in addition to diffuse edema of both sacral wings, supportive of bilateral sacral insufficiency fractures

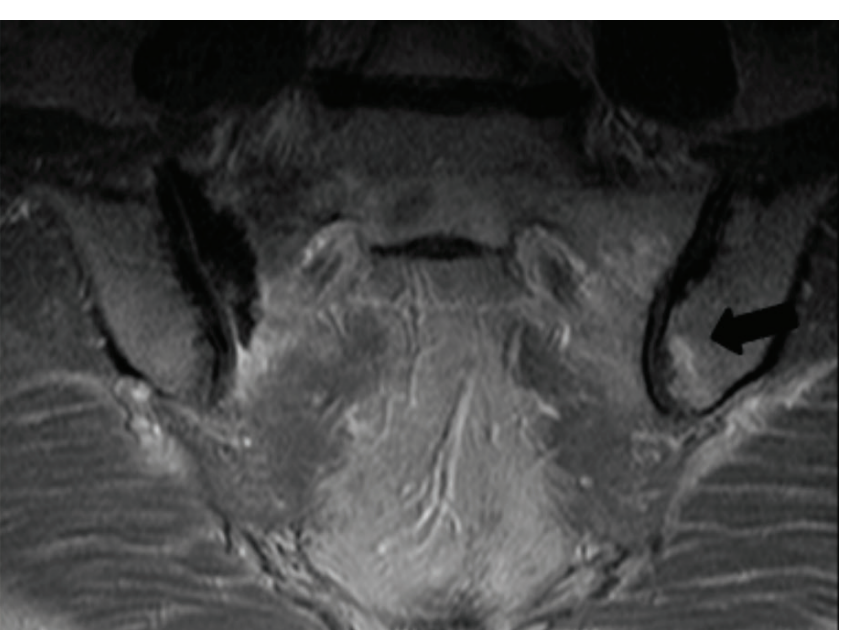

Figure 1. (a) Post contrast T1-weighted image shows a hypointense line of insufficiency fracture in the sacrum (arrows). (b) In the postcontrast T1-weighted image of the osteoradionecrosis area on the left, a halo-like area that shows lower signal enhancement in the center and higher signal enhancement in the periphery is observed (thick arrow) 
usually heals between 16 and 40 months after RT but cases developing after up to 4 years post-RT have been reported (2). Pelvic osteoradionecrosis is rare and its incidence ranges from 2.1-34\% (5). Insufficiency fractures are more common than osteonecrosis. After RT of the pelvic area, osteonecrosis is most frequently seen in sacrum but in our patient, osteoradionecrosis was observed in the iliac wing, which is a rare type of pelvic osteoradionecrosis.

An important sequela of RIR in the pelvic skeleton, with or without clinical symptoms, is progressive biomechanical bone instability, which can ultimately lead to insufficiency fractures. Sacral insufficiency fracture was first described in 1982 by Lourie (4). It occurs when bone tissue with reduced elasticity is exposed to normal stress $(1,6,7)$. It is reported that the incidence reported as $1.8 \%$ may be higher due to undiagnosed cases $(6,7)$. The risk of insufficiency fracture, which is one of the rarer causes of low back and hip pain, increases with RT $(7,8)$. The risk of fractures is higher in women than in men and is generally associated with higher radiation doses (9). Insufficiency fractures due to pelvis radiation are rare at doses less than $40 \mathrm{~Gy}$. The risk of fractures increases over 40 Gy (9). In our patient, a total of 59.4 Gy of RT was applied which may have contributed to the development of an insufficiency fracture.

Insufficiency fracture, characteristically symmetrical in the sacral ala and pubic bones is seen within 1 year following RT in postmenopausal women, and it may usually be misdiagnosed as a metastatic lesion (9). MRI and computerized tomography (CT) are helpful in the differential diagnosis. The presence of other lumbar spinal degenerative lesions and lack of specific symptoms/examination findings in the early period may delay the diagnosis of osteonecrosis.

It may be difficult to differentiate insufficiency fractures from metastatic disease with conventional X-rays. Therefore, best imaging method to evaluate bone marrow changes after radiotherapy is MRI. CT may also be used for fracture detection and ruling out metastases (3). In a study by Meixel et al. (3), 410 patients with pelvic malignancies were examined with MRI. New pathological signal changes were detected in $17.6 \%$, radiation osteitis in $83.3 \%$, and definite osteonecrosis in $16.7 \%$ of the patients. Thirty-one patients $(43.1 \%)$ had sacral insufficiency fracture. Feltl et al. (10) reviewed 3,155 patients who received radiotherapy for treatment of pelvic malignancies and reported that 15 patients developed pelvic fractures due to osteoradionecrosis. These 15 patients were also diagnosed with osteoporosis. Patients with osteoporosis are probably at the highest risk of developing osteoradionecrotic fractures after pelvic RT. Our case subject did not have osteoporosis but still developed bilateral insufficiency fractures and osteonecrosis after RT.

During the course of osteoradionecrosis, after the initial phase of bone marrow edema, which lasts for several weeks, fatty bone marrow transformation takes place (11). Radiotherapy can directly lead to bone necrosis. This usually leads to sclerotic bone changes of the trabecula and cortex. And this process in turn leaves the bone vulnerable to insufficiency fractures (11). Our patient's third month MRI revealed a more pronounced bilateral diffuse fatty bone marrow as well as a second insufficiency fracture on the left side of the sacrum, which signals to the ongoing nature of late- term radiation injury.

Sacral bone marrow changes due to radiotherapy are frequently seen after pelvic radiotherapy. It occurs early during the course of therapy and usually resolves within time. Radiation-osteitis is more common, while osteoradionecrosis is relatively rare. Insufficiency fractures are less commonly seen late toxic effects of RT.

Red flags such as the presence of a history of RT in the presence of low back pain may direct the clinician towards a possibility of radiation induced reactions, especially in older or osteoporotic patients. As in our case presentation, patients may present with severe pain due to an acute insufficiency fracture or iliac wing osteonecrosis. Although sacral or femoral head osteonecrosis is frequently seen, it can also rarely develop in the iliac wing and be misdiagnosed as mechanical pain or a metastatic lesion. In patients with a history of RT, other more common differential diagnoses of low back pain should also be kept in mind.

\section{Ethics}

Informed Consent: We obtained consent from the patient for the case report.

Peer-review: Externally and internally peer-reviewed.

\section{Authorship Contributions}

Surgical and Medical Practices: S.H., E.C.S., E.Y.G., E.Ç., Concept: S.H., E.Ç., Design: S.H., E.Ç., Data Collection or Processing: E.C.S., E.Y.G., E.Ç., I.T., Analysis or Interpretation: S.H., E.C.S., E.Y.G., E.Ç., I.T., Literature Search: E.C.S., E.Y.G., E.Ç., Writing: E.C.S., E.Y.G., E.Ç.

Conflict of Interest: No conflict of interest was declared by the authors.

Financial Disclosure: The authors declared that this study received no financial support

\section{References}

1. Dalinka MK, Edeiken J, Finkelstein JB. Complications of radiation therapy: adult bone. Semin Roentgenol 1974;9:29-40.

2. Chung KY, Chiu KH, Cheung KW. Osteoradionecrosis of the acetabulum in a total hip arthroplasty: a case report. J Orthop Surg (Hong Kong) 2010;18:110-2.

3. Meixel AJ, Hauswald H, Delorme S, Jobke B. From radiation osteitis to osteoradionecrosis: incidence and MR morphology of radiationinduced sacral pathologies following pelvic radiotherapy. Eur Radiol 2018;28:3550-9.

4. Lourie H. Spontaneous osteoporotic fracture of the sacrum. An unrecognized syndrome of the elderly. JAMA 1982;248:715-7.

5. Abe H, Nakamura M, Takahashi S, Maruoka S, Ogawa Y, Sakamoto K. Radiation-induced insufficiency fractures of the pelvis: evaluation with 99mTc-methylene diphosphonate scintigraphy. AJR Am J Roentgenol 1992;158:599-602.

6. Bostel T, Sterzing F. Radiotherapy. In: Kauczor HU, Bäuerle T. (eds) Imaging of Complications and Toxicity following Tumor Therapy. Medical Radiology. Springer, Switzerland. 2014

7. Ugurluer G, Akbas T, Arpaci T, Ozcan N, Serin M. Bone complications 
after pelvic radiation therapy: evaluation with MRI. J Med Imaging Radiat Oncol 2014;58:334-40.

8. Kim HJ, Boland PJ, Meredith DS, Lis E, Zhang Z, Shi W, et al Fractures of the sacrum after chemoradiation for rectal carcinoma: incidence, risk factors, and radiographic evaluation. Int J Radiat Oncol Biol Phys 2012;84:694-9.

9. Withers HR, Peters LJ, Taylor JM. Dose-response relationship for radiation therapy of subclinical disease. Int J Radiat Oncol Biol Phys 1995;31:353-9.
10. Feltl $D$, Vosmik $M$, Jirásek $M$, Stáhalová $V$, Kubes J. Symptomatic osteoradionecrosis of pelvic bones in patients with gynecological malignancies-result of a long-term follow-up. Int J Gynecol Cancer 2006:16:478-83.

11. Daldrup HE, Link TM, Blasius S, Strozyk A, Könemann S, Jürgens $\mathrm{H}$, et al. Monitoring radiation-induced changes in bone marrow histopathology with ultra-small superparamagnetic iron oxide (USPIO)-enhanced MRI. J Magn Reson Imaging 1999;9:643-52. 